\title{
EFFECTS OF SOME EDIBLE OILS ON BLOOD COMPOSITION IN EXPERIMENTAL ANIMALS
}

\author{
M. A. Habieb, Hoda A. Farid, S. M. El-Sayed and Fatma K. Ibrahim \\ Biochemistry Department, Faculty of Agriculture, Menofia University, \\ Shibin El-Kom, Egypt
}

Received: Jul. 31,2018

Accepted: Aug. 9 , 2018

\begin{abstract}
The present work aims to study the potential effect of edible oils like olive, sunflower and flaxseed oils to give more protection against harmful effect of frying oil used in preparation of Tamiya (Falafel). Chemical and physical properties of oils were determined, also fatty acids composition of oils were identified. To study the harmful effect of oils used in preparation of falafel, twenty five of male albino rats were used over 45 days period. The animals were divided into (5) groups, wherein groups number (1) represent control which were fed on basal diet, while group number (2) was received $15 \%$ frying oil . Other three groups allowed to feed on high $15 \%$ frying oil with olive oil (5\%) group number (3), sunflower oil (5\%) group numer (4) and flaxseed oil (5\%) group number (5). At the end of the experimental period, blood samples were collected to determine lipid profile include triglyceride, total cholesterol , HDL- cholesterol and LDL cholesterol. The kidney functions include urea nitrogen and creatinine. From the obtained results, it concluded that group of rats fed on $15 \%$ frying oil were considered as a major risk factor for hyperlipidemia disease. The obtained results could be summarized that edible oils like olive oil, sunflower oil and flaxseed oil were considered the best for causing a reduction of TC, TG and LDL. Also, kidney function has been improved and there were a significant reduction urea than that of positive control group.
\end{abstract}

Key wards: Frying oils - Edible oils - Triglycerides - Cholesterol - kidney_functions.

\section{INTRODUCTION}

Tamiya (Falafel) is the most popular fried food product used by almost all Egyptians. It is a cheap, easily and quickly prepared, taste full and has a quite national value. Preparation of Tamiya in frying pastes contain broad bean , garlic , onion, Egyptian leek and spiced minced and frying in edible oil. Longtime and deep boiling of edible oil during the frying process gives to formation of free radicals and other harmful agents .

Frying is one of the oldest and simplest methods of food cooking, and it remains very popular. Frying involves putting food in contact with hot oil for various periods of time to withdraw the thermal energy and cook the food as mentioned by Rossell (2001). No matter where or when frying originated, it remains a cooking method widely used domestically, commercially and industrially as mentioned by Chapman (2012). Frying is fast, generates unique flavors and textures which cannot be created by other means, and can be accomplished with simple equipment as mentioned by Rossell (2001). The frying of food can be performed in a variety of ways such as pan frying, deep fat frying, stir frying, and sauteing. Each type of frying can be modified to suit the needs of the individuals carrying out the frying process. Deep fat frying is an important food preparation process in the food industry because it is fast, convenient, and produces highly accepted foods amongst consumers. Unique properties of fats and oils provide a distinctive flavor, odor, and pleasing mouth-feel to 
fry food products as mentioned by Orthoefer et. al, (2006a).

Due to oxygen absorption from the oilair interface, leaching of food components, and the breakdown of oil constituents, a mixture of hundreds of chemical components is formed. The rapidly degrading frying oil can produce compounds that reduce oil quality, be absorbed by the fried food to create offflavors, and cause a decrease in the nutritional value of the fried food as mentioned by Orthoefer et. al, (2006b). This can potentially become hazardous as highly oxidized oils have been linked to deleterious health effects in mice causing weight loss, liver and kidney damage, and intestinal tumours as mentioned by Paul et al., (1997) and Stier, (2001). Three major types of reactions have been documented during frying: hydrolysis, oxidation and polymerization. Hydrolysis of ester bonds due to the moisture introduced by foods releases long-chain free fatty acids. Oxidation takes place due to the presence of air, and dimers and polymers are formed by radical recombination to form -C-C-, -COC-, and -C-O-O-C- bonds as mentioned by Sahin, and Sumnu (2009) , Gupta (2005) . The first health concern is the use of saturated frying oils such as animal fats. Saturated fats have been proven to increase low-density cholesterol (LDL) and reduce highdensity cholesterol (HDL) as mentioned by Bockisch (1998). The changes in cholesterol level will promote the risk of cardiovascular disease such as hypertension, heart attack and stroke. Although initial studies focused on the overall Mediterranean diet, more recent studies compare a diet rich in olive oil to one low in olive oil. These studies provided a good evidence olive oil may be beneficial for reducing high blood pressure and preventing breast and colon cancer. In vitro studies have been designed to identify how olive oil exerts its effects at the cellular level. The antioxidant capacity of olive oil contributes to many of its health benefits. The antioxidant action of olive oil in vitro has been highly documented and linked to such benefits as chemoprotection, anti-inflammatory action, and prevention of atherosclerotic plaque formation. as mentioned by Emily et al., (2007).

Flaxseed oil or blends of flaxseed oil and sunflower oil promoted cholesterol reduction in hypercholesterolemic rats as compared to diets formulated with hard fats. These authors suggested that a diet with the appropriate balance of $n-6$ and $n$ 3 fatty acids was preferred over diets high in n-6 fatty acids Ranhotra et al. (1992). Ground flaxseed is high in omega3 fatty acids which have been shown to reduce hypertension, cholesterol and triglyceride level Oomah and Maza, (1998).

Sunflower oil is very high in polyunsaturated fatty acids and ranges between 64 and 68 percent. From a nutritional standpoint, this is desirable, because polyunsaturates are the source of essential fatty acids necessary for the production of prostaglandins. Prostaglandins play major roles in protecting the cardiovascular, reproductive, and immune and central nervous system Madhavi et al., (2010).

\section{MATERIALS AND METHODS Materials:}

The olive oil, sunflower oil and flaxseed oil samples were collected from local market. Tamiya boiled oil was collected from 3 different restaurants in Shebin El-Kom city, El-Minufia Governorates randomly. 
Methods :

Physico-chemical properties of the oils:

The physico-chemical properties (saponification value, acid value, ester number, peroxide value, iodine value , specific gravity, viscosity and refractive index).of the oil were carried out using the method described by (A.O.A.C 1990).

\section{Identification of fatty acids:}

Saturated, unsaturated and total fatty acids were determinated in the oil by using methyl esters boron trifluoride method A.O.A.C (2012), the oil is saponified with sodium hydroxide in methanol .The fatty acids are methylised with boron tri fluoride in methanol, extracted with heptanes and determined on a gas chromatograph with FID detector (PE auto system XL) with auto sampler and Ezchrom integration system. Carrier gas (He), ca.25 Psi -air $450 \mathrm{ml} / \mathrm{min}$ -Hudrogen $45 \mathrm{ml}$ - split $10 \mathrm{ml} / \mathrm{min}$. oven temperature $200^{\circ} \mathrm{C}$ injector and detector $250^{\circ} \mathrm{C}$.

\section{Biological Evaluation} Animals:

Adult male albino rats Sprague Dawely strain weighing between (90 - 100 gm ), were obtained from the animal house of Egyptian Organization for biological Products and Vaccines (VACSERA) Cairo, Egypt. The animals were kept in wire cages with wire bottom. The diet was introduced to the rats in special feed cup that kept food spilling to a minimum, water was provided to the rats by means of glass tube projecting through wire cage, an inverted bottle supported one side of the cage. The basal diet was formulated according to AIN - 93M, according to Reeves et al., (1993). The used vitamin mixture component was that recommended by Campbell (1963) while the salt mixture used was formulated according to Hegsted (1941).

\section{Experimental Design:}

Twenty five rats were divided into five groups : group (A) control fed on basal diet, groups (B, C , D and E ) were allowed to feed $15 \%$ Tamiya boiled oil through the feeding period. One of each experiment continued feeding $15 \%$ Tamiya boiled oil without any supplementation saved as TBO group (B) and the other three groups of each experiment were allowed to feed $15 \%$ Tamiya boiled oil with olive oil $(5 \%)$ as group (C), sunflower oil (5\%) as group (D) and flaxseed oil (5\%) as group (E).

\section{Blood sampling and analysis}

Blood samples were collected after six weeks in tubes contain heparin as an anticoagulant from the eye plexuses under diethyl ether anesthesia and then centrifuged at $3000 \mathrm{rpm}$ for $20 \mathrm{~min}$. To obtain plasma, which was kept frozen until analysis. The total cholesterol was analyzed calorimetrically according to Allain et al (1974) method. HDL cholesterol was determined according to Lopez et al. (1977) method . LDLcholesterol was calculated according to formula of Kikuchi et al., (1998). The triglycerides were analyzed according to Fossati and Prencipe (1982) method. Urea and creatinine were determined according to Young (2001).

\section{Statistical analysis}

The results of the animal experiments were expressed as the Mean \pm SE and they were analyzed statistically using the one-way analysis of variance ANOVA followed by Duncan's test. In all cases $p$ $\leq 0.05$ was used as the criterion of statistical significance.

\section{RESULTS AND DISCUSSION \\ Physical and chemical characteristics of olive oil , sunflower oil and flaxseed oil:}


Table (1) showed the physicochemical properties of edible oils. Acid values were $1.53 \mathrm{mg} \mathrm{KOH} / \mathrm{g}$ for olive oil, $0.42 \mathrm{mg} \mathrm{KOH} / \mathrm{g}$ for sunflower oil and 0.85 $\mathrm{mg} \mathrm{KOH} / \mathrm{g}$ for flaxseed oil. The acid value was lower than the Codex standard value for virgin vegetable oils $(4.0 \mathrm{mg}$ $\mathrm{KOH} / \mathrm{g}$ Oil). The peroxide values were 3.27 Meq/kg for olive oil , $0.97 \mathrm{Meq} / \mathrm{kg}$ for sunflower oil and $2.64 \mathrm{Meq} / \mathrm{kg}$ for flaxseed oil. The value was lower than the codex standard value (up to $10 \mathrm{Meq} / \mathrm{kg}$ ) for refined vegetable oil and lower than the maximum value $(20 \mathrm{Meq} / \mathrm{kg})$ allowed for unrefined olive oil (FAO/WHO, 1993). This implies that the oils have lower degree of rancidity. Also, iodine value were $74.14,137.1$ and 201.93 for olive oil, sunflower oil and flaxseed oil, respectively. The lower iodine value signifies low degree of unsaturation and the lesser the liability of the oil to become rancid by oxidation. The saponification values were $198.18 \mathrm{mg}$ $\mathrm{KOH} / \mathrm{g}$ for olive oil , $196.89 \mathrm{mg} \mathrm{KOH} \mathrm{/} \mathrm{g}$ for sunflower oil and $202.53 \mathrm{mg} \mathrm{KOH} \mathrm{/} \mathrm{g}$ for flaxseed oil. The refractive index at $25{ }^{\circ} \mathrm{C}$ were $1.466,1.469$ and 1.478 for olive oil, sunflower oil and flaxseed oil, respectively . Specific gravity and viscosity were 0.91 and $140 \mathrm{cp} / \mathrm{s}$ for olive oil , 0.925 and $130 \mathrm{cp} / \mathrm{s}$ for sunflower oil and 0.93 and $130 \mathrm{cp} / \mathrm{s}$ for flaxseed oil .

These results agreed with those previously reported by many other investigation Ibrahim (2000) and Firestone (1999), they found that Refractive index, acid number, iodine number and saponification number for flaxseed oil $1.4765-1.4779,1.57-1.78$ $\mathrm{mg} / \mathrm{g}, 189.7$ - $202.3 \mathrm{~g} / 100 \mathrm{~g}$ and 195.3 $203.5 \mathrm{mg} \mathrm{KOH} / \mathrm{g}$, respectively. Also Ibrahim et al., (2000) reported, peroxide value ranged between $6.58 \mathrm{meq} 02 / \mathrm{kg}$ and $10.14 \mathrm{meq} 02 / \mathrm{kg}$, saponification number from $187.05 \mathrm{mg} \mathrm{KOH} / \mathrm{g}$ to 194.85 $\mathrm{mg} \mathrm{KOH} / \mathrm{g}$. lodine value ranged from (79.44 - $91.38 \mathrm{~g}$ of iodine $/ 100 \mathrm{~g}$ oil), and refractive index ranged from (1.4688 1.4702), for olive oil.

\section{Fatty acids composition:}

As shown in Table ( 2 ), the fatty acid profiles of olive oil, sunflower oil and flaxseed oil are presented. In fatty acids composition of olive oil. Only 3 saturated fatty acids from $\mathrm{C} 16$ to $\mathrm{C20}$ and five unsaturated fatty acids from C18:1 to 20:1 including some highly unsaturated fatty acids such as C18:1 w9 (Oleic acid) , C18:2 $\omega 6$ (Linoleic acid) and C18:3 $\omega 3$ (linolenic acid) which recorded $74.25 \%$, $6.82 \%$ and $0.65 \%$, respectively .The fatty acids i.e. (PUFA) play an important role in human metabolic pathways, particularly as specific precursors for prostaglandin E1 Mendes et. al., (2006). The unsaturated fatty acids are very important for the stability of oils because of the chemical reactions occurring at the double bonds. The rate of those oxidation reactions depend on the number of double bonds in the carbon chain. Therefore, olive oil with high proportion of oleic acid are more stable than the others. Also, oleic acid is less susceptible to oxidation than polyunsaturated fatty acid from the $n-6$ series (linoleic acid). The fatty acid profiles of sunflower oil, four saturated fatty acids from C16 to C21 and three unsaturated fatty acids from C18:1 to 18:2 including C18:1 w9 (oleic acid) , C18:1 $\omega 7$ (Vaccinic acid) and C18:2 w6 (linoleic acid) which recorded 27\% , 1\% and $61.86 \%$, respectively. In fatty acids composition of flaxseed oil, two saturated fatty acids from C16 to C18 including palmitic and stearic acids which recorded $5.26 \%$ and $4.15 \%$ respectively, and four unsaturated fatty acids from C18:1 to 18:3 including C18:1 $\omega 9$ (oleic acid) , C18:1 $\omega 7$ (Vaccinic acid), C18:2 $\omega 6$ (linoleic acid) and C18:3 $\omega 3$ (linolenic acid) which recorded $17 \%$, $0.87 \%, 15.6 \%$ and $57.65 \%$, respectively. 
Effects of some edible oils on blood composition in experimental

Table (1): Physical and Chemical properties of oils

\begin{tabular}{|c|c|c|c|}
\hline Parameters & Olive oil & Sunflower oil & Flaxseed oil \\
\hline Refractive index & 1.466 & 1.469 & 1.478 \\
\hline Specific gravity & 0.91 & 0.925 & 0.93 \\
\hline Viscosity cp/s & 140 & 130 & 130 \\
\hline Acid value $\mathrm{mg} / \mathrm{g}$ & 1.53 & 0.42 & 0.85 \\
\hline Peroxide value Meq/kg & 3.27 & 0.97 & 2.64 \\
\hline Saponification value $\mathrm{mg} \mathrm{KOH} / \mathrm{g}$ & 198.18 & 196.89 & 202.53 \\
\hline lodine value g/100g & 74.14 & 137.1 & 201.93 \\
\hline
\end{tabular}

Table 2: Fatty acids composition of olive, sunflower and flaxseed oil

\begin{tabular}{|c|c|c|c|}
\hline \multirow{2}{*}{ Name of fatty acid } & \multicolumn{3}{|c|}{ Relative distribution (\%) } \\
\hline & Olive oil & Sunflower oil & Flaxseed oi \\
\hline $\begin{array}{c}\text { Palmitic acid } \\
\text { C16:0 }\end{array}$ & 11.16 & 5.93 & 5.26 \\
\hline Stearic acid C18:0 & 2.05 & 3.31 & 4.15 \\
\hline $\begin{array}{r}\text { Oleic acid C18:1 } \\
\omega 9\end{array}$ & 74.25 & 27.0 & 17.0 \\
\hline $\begin{array}{c}\text { Vaccinic acid } \\
\text { C18:1 } \omega 7\end{array}$ & 3.69 & 1.0 & 0.87 \\
\hline $\begin{array}{l}\text { Linoleic acid } \\
\text { C18:2 w6 }\end{array}$ & 6.82 & 61.86 & 15.6 \\
\hline $\begin{array}{c}\text { Arachidic acid } \\
\text { C20:0 }\end{array}$ & 0.43 & 0.23 & ------ \\
\hline $\begin{array}{c}\text { Eicosaenoic acid } \\
\text { C20:1w11 }\end{array}$ & 0.31 & ----- & ------ \\
\hline $\begin{array}{c}\text { Linolenic acid } \\
\text { C18:3 w3 }\end{array}$ & 0.65 & ----- & 57.65 \\
\hline $\begin{array}{c}\text { Behenic acid } \\
\text { C21:0 }\end{array}$ & ----- & 0.65 & -------- \\
\hline
\end{tabular}

Content of linoleic acid (C18:2) and linolenic acid (C18:3) as an essential fatty acid in the oils may be provide high nutritional remuneration and render beneficial healthy effect on blood lipid, blood pressure and cholesterol contents Cheikh-Rouhou, et al. (2008) and it is preferred by industries when oil hydrogenation is required. 
In vivo study of the effect of frying oil and olive, sunflower and flaxseed oils on rats:

Data in Table (3) indicates the level of plasma triglycerides, plasma total cholesterol, HDL- cholesterol and LDLcholesterol of rats fed on basal diet, basal diet supplemented with 15\% TBO, basal diet supplemented with 15\% TBO + $5 \%$ olive oil , basal diet supplemented with $15 \%$ TBO $+5 \%$ sunflower oil and basal diet supplemented with $15 \%$ TBO + $5 \%$ flaxseed oil for 45 days. Data indicated that plasma triglycerides were $175.4 \pm 3.3 \mathrm{mg} / \mathrm{dl}$ after 45 days of feeding on $15 \%$ TBO while in normal group which feeding on standard diet triglycerides reached $97.4 \pm 1.3 \mathrm{mg} / \mathrm{dl}$, meanwhile after 45 days of feeding on 15\% TBO but contain $5 \%$ of olive oil , sunflower oil and flaxseed oil triglycerides reached 119.4 $\pm 3.5,122.2 \pm 2.2$ and $128.4 \pm 2.3 \mathrm{mg} / \mathrm{dl}$ respectively. Plasma total cholesterol were $82.4 \pm 6.1 \mathrm{mg} / \mathrm{dl}$ after 45 days of feeding on $15 \%$ TBO while in normal group which feeding on standard diet total cholesterol reached $68 \pm 3.8 \mathrm{mg} / \mathrm{dl}$, meanwhile after 45 days of feeding on $15 \%$ TBO but contain $5 \%$ of olive oil , sunflower oil and flaxseed oil total cholesterol reached $73.8 \pm 5.3,74.6 \pm 5.1$ and $74.8 \pm 5.1 \mathrm{mg} / \mathrm{dl}$ respectively. Plasma HDL-cholesterol were $34 \pm 2.2 \mathrm{mg} / \mathrm{dl}$ after 45 days of feeding on 15\% TBO while in normal group which feeding on standard diet HDL-cholesterol reached $42.2 \pm 1.9$ $\mathrm{mg} / \mathrm{dl}$, meanwhile after 45 days of feeding on $15 \%$ TBO but contain $5 \%$ of olive oil , sunflower oil and flaxseed oil HDLcholesterol reached $37.4 \pm 1.6,35.4 \pm 2.6$ and $36.6 \pm 2.6 \mathrm{mg} / \mathrm{dl}$ respectively. Plasma LDL-cholesterol of rats were $48.4 \pm 1.9$ $\mathrm{mg} / \mathrm{dl}$ after 45 days of feeding on $15 \%$ TBO while in normal group which feeding on standard diet LDL-cholesterol reached $25.8 \pm 1.3 \mathrm{mg} / \mathrm{dl}$, meanwhile after 45 days of feeding on $15 \%$ TBO but contain $5 \%$ of olive oil , sunflower oil and flaxseed oil LDL-cholesterol reached $36.4 \pm 1.8,39.2$ \pm 2.1 and $38.2 \pm 2.3 \mathrm{mg} / \mathrm{dl}$ respectively.

These results are agreed with Craig, (1999), who mentioned that, a high ALA flaxseed diet was associated with reduced levels of TG and TC. Also, Vijaimohan et al., (2006) mentioned that ALA supplementation significantly lowered the increased levels of plasma TC, TG, LDL-cholesterol, LDL/HDLcholesterol, and TC/HDL-cholesterol . Also, Djousse et al., (2003) stated that ALA intake at 0.81 and $0.69 \mathrm{~g} / \mathrm{d}$ in men and women significantly reduced plasma TG levels.

Data in Table (4) indicates the level of plasma creatinine of rats .Plasma creatinine were $0.9 \pm 0.1 \mathrm{mg} / \mathrm{dl}$ after 45 days of feeding on $15 \%$ TBO while in normal group which feeding on standard diet creatinine reached $0.86 \pm 0.11 \mathrm{mg} / \mathrm{dl}$, meanwhile after 45 days of feeding on $15 \%$ TBO but contain $5 \%$ of olive oil , sunflower oil and flaxseed oil creatinine reached $0.8 \pm 0.07,0.76 \pm 0.05$ and $0.84 \pm$ $0.16 \mathrm{mg} / \mathrm{dl}$ respectively. Plasma urea of rats were $42.6 \pm 1.51 \mathrm{mg} / \mathrm{dl}$ after 45 days of feeding on $15 \%$ TBO while in normal group which feeding on standard diet urea reached $40.1 \mathrm{mg} / \mathrm{dl}$, meanwhile after 45 days of feeding on $15 \%$ TBO but contain $5 \%$ of olive oil , sunflower oil and flaxseed oil urea reached $34.6 \pm 1.67$, $41.8 \pm 0.83$ and $39.8 \pm 1.48 \mathrm{mg} / \mathrm{dl}$ respectively.

After $\mathbf{4 5}$ days, the supplementation of olive oil and flaxseed oil to basal diet containing TBO decreased significantly plasma urea to $34.6 \pm 1.67$ and $39.8 \pm$ $1.48 \mathrm{mg} / \mathrm{dl}$ respectively, compared with TBO group $42.6 \pm 1.51 \mathrm{mg} / \mathrm{dl}$. 
Table (3): Effect of olive, sunflower and flaxseed oil on plasma triglycerides, total cholesterol, HDL and LDL-cholesterol in rats feeding Tamiya boiled oil for $\mathbf{4 5}$ days.

\begin{tabular}{|c|c|c|c|c||}
\hline Group & $\begin{array}{c}\text { Triglycerides } \\
(\mathrm{mg} / \mathrm{dl})\end{array}$ & $\begin{array}{c}\text { Total } \\
\text { cholesterol } \\
(\mathrm{mg} / \mathrm{dl})\end{array}$ & $\begin{array}{c}\text { HDL-C } \\
(\mathrm{mg} / \mathrm{dl})\end{array}$ & $\begin{array}{c}\text { LDL--C } \\
(\mathrm{mg} / \mathrm{dl})\end{array}$ \\
\hline Control & $97.4 \pm 1.3^{\mathrm{a}}$ & $68 \pm 3.8^{\mathrm{a}}$ & $42.2 \pm 1.9^{\mathrm{c}}$ & $25.8 \pm 1.3^{\mathrm{a}}$ \\
\hline TBO & $175.4 \pm 3.3^{\mathrm{d}}$ & $82.4 \pm 6.1^{\mathrm{b}}$ & $34 \pm 2.2^{\mathrm{a}}$ & $48.4 \pm 1.9^{\mathrm{c}}$ \\
\hline TBO + olive & $119.4 \pm 3.5^{\mathrm{b}}$ & $73.8 \pm 5.3^{\mathrm{a}}$ & $37.4 \pm 1.6^{\mathrm{b}}$ & $36.4 \pm 1.8^{\mathrm{b}}$ \\
\hline TBO+sunflower & $122.2 \pm 2.2^{\mathrm{b}}$ & $74.6 \pm 5.1^{\mathrm{a}}$ & $35.4 \pm 2.6^{\mathrm{ab}}$ & $39.2 \pm 2.1^{\mathrm{b}}$ \\
\hline TBO+flaxseed & $128.4 \pm 2.3^{\mathrm{c}}$ & $74.8 \pm 5.1^{\mathrm{a}}$ & $36.6 \pm 2.6^{\mathrm{ab}}$ & $38.2 \pm 2.3^{\mathrm{b}}$ \\
\hline
\end{tabular}

Values represent means \pm S.E obtained from 5 animals.

Means in the same column followed by the same letters do not differ significantly, and when the means followed by different letters differ significantly at $(P \leq 0.05)$.

Table (4): Effect of olive, sunflower and flaxseed oil on plasma creatinine and urea in rats feeding Tamiya boiled oil for 45 days

\begin{tabular}{|c|c|c|}
\hline Group & $\begin{array}{c}\text { Creatinine } \\
\text { mg/dl }\end{array}$ & $\begin{array}{c}\text { urea } \\
\mathrm{mg} / \mathrm{dl}\end{array}$ \\
\hline Control & $0.86 \pm 0.11^{\mathrm{a}}$ & $40.1 \pm 1.78^{\mathrm{b}}$ \\
\hline TBO & $0.9 \pm 0.1^{\mathrm{a}}$ & $42.6 \pm 1.51^{\mathrm{c}}$ \\
\hline TBO + olive & $0.8 \pm 0.07^{\mathrm{a}}$ & $34.6 \pm 1.67^{\mathrm{a}}$ \\
\hline TBO+sunflower & $0.76 \pm 0.05^{\mathrm{a}}$ & $41.8 \pm 0.83^{\mathrm{c}}$ \\
\hline TBO+flaxseed & $0.84 \pm 0.16^{\mathrm{a}}$ & $39.8 \pm 1.48^{\mathrm{b}}$ \\
\hline
\end{tabular}

Values represent means \pm S.E obtained from 5 animals.

Means in the same column followed by the same letters do not differ significantly, and when the means followed by different letters differ significantly at $(P \leq 0.05)$.

\section{REFERENCES}

A.I.N. American institute of Nutrition. (1993). Purified dite for laboratory Rodent. Final report. J. Nutrition, 123:1939-1951.

Allain, C.C., L.S. Poon, C.S.G. Chan, W. Richmond and P.C. Fu (1974). Clin Chem, 20: 470.

A.O.A.C. (1990). 15th Official methods of Analysis. Association Official Analysis
Chemists, Washington D.C. USA. Pp. 807-928.

A.O.A.C. (2012). Official methods of analysis of the Association of Official Analytical Chemists . International No. 994. 12. chapter $4, P \cdot 9-13.19^{\text {th }}$ Edition.

Bockisch, M. (1998). Fats and oils handbook. Champaign, IL: AOCS Press. $\quad$ pp. $\quad 838$. Campbell, J.A. (1963). Methodology of 
protein Evaluation . RGA Nutr. Document R. Led.37. June Meeting, Newyork

Chapman, M. (2012). Fried in the future. Prepared Foods [Online], http://www.preparedfoods.com/article s/print/111896-fried-in-the-future (accessed March 12, 2013).

Cheikh-Rouhou, S., S. Besbes, G. Lognay, C. Blecker, C. Deroanne and H. Attia (2008). Sterol composition of black cumin (Nigella sativa, L.) And Aleppo Pine (Pinus halepensis, Mill.) seed oils. Journal Food Composition Analysis. 21: 162-168.

Craig, W.J. (1999). "Health-promoting properties of common herbs." Am J Clin. Nutr., 70:491-499.

Djousse, L., S.C. Hunt, D.K. Arnett, M.A. Province, J.H. Eckfeldt and R.C.Ellison (2003). "Dietary linolenic acid is inversely associated with plasma triacylglycerol: the National Heart, Lung, and Blood Institute Family Heart Study." Am J Clin. Nutr., 78:1098-1102.

Emily Waterman, MPharm and Brian Lockwood (2007). Active components and clinical applications of olive oil , Alternative Medicine Review ,12, (4): $331-342$.

FAO/WHO (1993). Fats, oils and related product. Food standard program. Codex Alimentarius Commission. Food and Agriculture Organization of the United Nations. World Health Organization, Rome. 8: 33-35.

Firestone, D. (1999). Corn oil, in Physical and Chemical Characteristics of Oils,Fats and Waxes, American oil Chemistry Society, Champaign,IL,PP.31-32 Physical and Chemical Characteristics of oils, fats and waxes, AOCS press, Champaign, Illinois,1999,pp·152.

Fossati, F. and L. Prencipe (1982). Plasma triglycerides determined colorimetrically with an enzyme that produces hydrogen peroxide. J.Clin.Chem., 28 (10): 2077 - 2080.
Gupta, M. K. (2005). Frying Oils. In Bailey's Industrial oil \& Fat Products, 6 ed.; Shahidi, F., Ed. WileyInterscience: Canada,. Rossell, J. B., Frying - Improving Quality. Woodhead Publishing: 2001.

Hegested, D., R. Mills and E. Perkins (1941). Salt mixture. J.Biol.Chem.,138:459.

Ibrahim Hassan Abdalla, M. khaddor, A. Boussab, D. El Garrouj and B. Souhial (2000). Physical and Chemical Characteristics of Olive Oils from Cooperatives for Olive Growers in the North of Morocco. International Journal of Basic \& Applied Sciences IJBAS-IJENS' 14 (02): 4-11.

Ibrahim, H.E.A. (2000). Chemical Studies on Some Vegetable oils. Sc.T thesis in Agric-Biochemistry,Fac-Agric,Cairo University ·

Kikuchi, H.H., N. Onodera., S. Matsubara, E. Yasuda, O. Chonan, R. Takahashi and F. Ishikawa (1998). Effect of soy milk and bifidobacterium fermented soy milk on lipid metabolism in aged ovariectomized rats. Bioscience, Biotechnology and Biochemistry . 62 (9) , $1688-1692$.

Lopez, M.F., S. Stone, S. Ellis and J.A. Collwell (1977). Cholesterol determination in high density lipoproteins separated by three different methods. Clin.Chem.,23(5):882 - 886.

Madhavi, B., N.K.D. Devi, B.S. Mrudula and R.N. Babu (2010). The importance of biodegradable bio-oil-sunflower. Int. J. Pham. Tech. Res., 2: 1913-1915.

Mendes, R.L., A.D. Reis and A.F. Palavra (2006). Supercritical $\mathrm{CO} 2$ extraction of $\mathrm{Y}$-linolenic acid and other lipids from Arthrospira : comparison with organic solvent extraction. Food. Chem. 99: 57-63.

Oomah, B.D., E.O. Kenaschuk and G. Mazza (1997). Tocopherols in flaxseed. Journal of Agricultural and Food Chemistry, 45:2076-2080. 
Orthoefer, F. T. and G. R. List (2006a). Dynamics of Frying. In: Erickson, $M$. D. (ed). Deep Frying: Chemistry, Nutrition, and Practical Applications (2nd edn). AOCS press, Champaign, IL, pp. 253-275.

Orthoefer, F. T. and G.R. List (2006b). Evaluation o f Used Frying Oil. In: Erickson, M. D. (ed). Deep Frying: Chemistry, Nutrition, and Practical Applications (2nd edn). AOCS press, Champaign, IL, pp. 329-342.

Paul, S., G. S. Mittal and M. S. Chinnan (1997). Regulating the Use of Degraded Oil/Fat in Deep-Fat/Oil Food Frying. Crit. Rev. Food Sci. Nutr, 37,635-662.

Ranhotra, G.S., J.A. Gelroth and B.K. Glaser (1992). Lipidemic response to rats fed flaxseed or sunflower oils. Cereal Chemistry, 69 (6): 623-625.

Rossell, J. B. (2001). Frying 1st Edition Improving Quality. Woodhead Publishing Limited, Cambridge, UK.
Sahin, S. and S. G. Sumnu (2009). Advances in Deep-fat Frying of Foods. Taylor \& Francis Group, LLC: Boca Raton, FL,.

Stier, R. F. (2001). The Measurement of Frying Oil Quality and Authenticity. In: Rossell, J. B. (ed). Frying: improving quality. Woodhead Publishing Limited, Cambridge, UK, pp. 165-193.

Vijaimohan, K., M. Jainu, K.E. Sabitha, S. Subramaniyam, C. Anandhan, Shyamala Devi C.S. (2006). "Beneficial effects of alpha linolenic acid rich flaxseed oil on growth performance and hepatic cholesterol metabolism in high fat diet fed rats." Life Sciences. 79:448-454.

Young, D.S. (2001). Effects of Disease on Clinical Lab.Tests. 4th ed AACC American Association for Clinical Chemistry

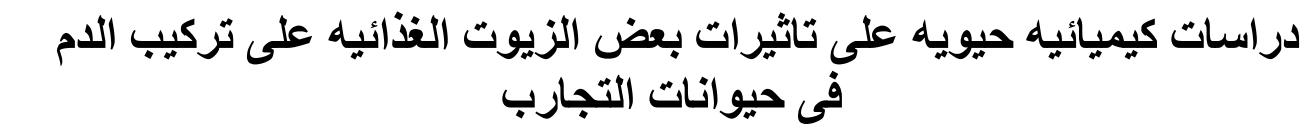

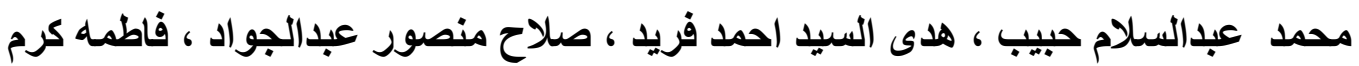

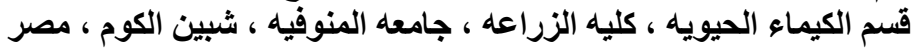




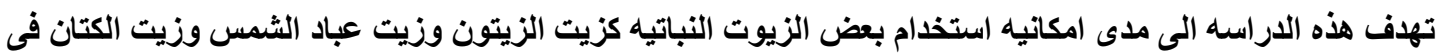

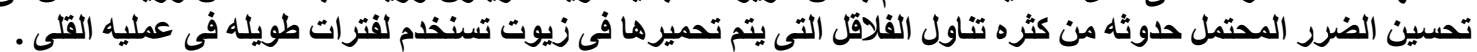

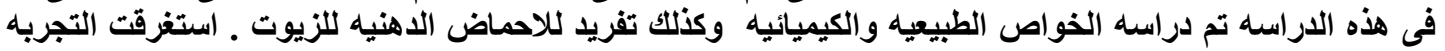

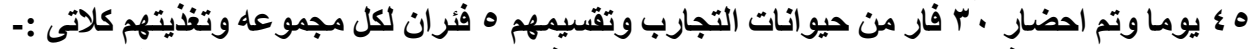

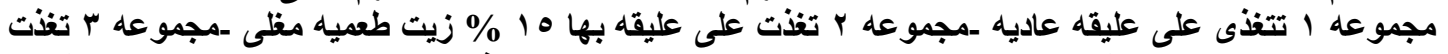

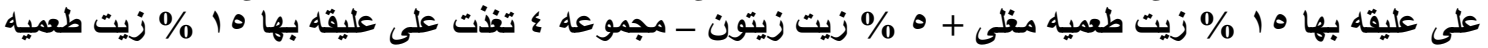

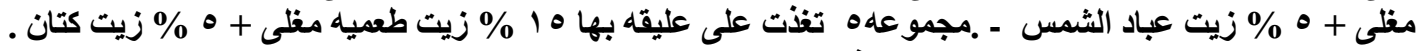

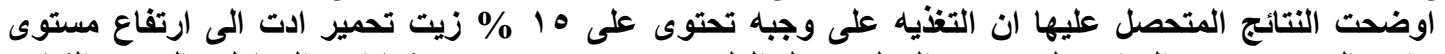

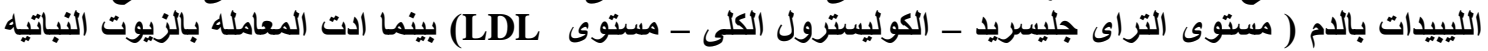
(زيت الزيتون - زيت عباد الثمس- زيت الكتان ) الى خفض مستوى الليبيدات بالام .

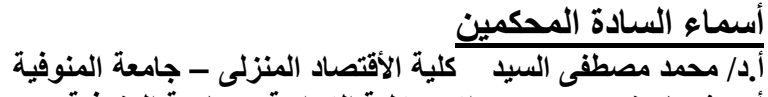

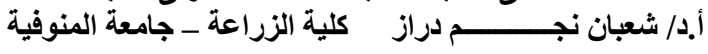

